J. Clin. Chem. Clin. Biochem.

Vol. 18, 1980, pp. 27-30

\title{
A Survey Report on the Determination of Total Bilirubin in Neonatal Samples
}

\author{
By B. G. Blïjenberg and B. Leïnse
}

Department of Clinical Chemistry, Academic Hospital Rotterdam-Dijkzigt, NL-3015 GD Rotterdam, The Netherlands

(Received June 27/September 14, 1979)

Summary: Three surveys were organized in the Rotterdam area with respect to the determination of total bilirubin in neonatal sera. Fifteen hospital laboratories participated. The coefficients of variation dropped from about $15 \%$ (survey 1) to about $8 \%$ (survey 3). This improvement was reached by discussing the techniques used, and in some cases by changing them.

\section{Bericht über Ringversuche zur Bestimmung des Gesamt-Bilirubins im Serum Neugeborener}

Zusammenfassung: Drei Ringversuche, an denen 15 Krankenhaus-Laboratorien im Gebiet von Rotterdam teilnahmen, wurden zur Bestimmung des Gesamt-Bilirubins im Serum Neugeborener organisiert. Die Variationskoeffizienten nahmen von Ringversuch 1 von $15 \%$ auf etwa $8 \%$ im Ringversuch 3 ab. Diese Verbesserung wurde durch Diskussion der angewandten Technik als auch teilweise deren Änderung erreicht.

\section{Introduction}

Surveys are nowadays accepted in clinical chemistry as useful tools in improving laboratory performance.

Sometimes those tools are the only means available. We met this situation when we wished to know the state of the art in the Rotterdam area with respect to the determination of total bilirubin in neonatal sera. For several reasons we were interested in the correlation between the methods used in the various laboratories:

1. From the development of our ACA-method for neonatal bilirubin the well known "clinical chemical rule" seemed to be fulfilled i. e. one method - one result (1). Fortunately the situation in our discipline is not always that negative, and our present study seems to bear this out. Nevertheless not all correlation studies gave identical results.

2. The assumed widespread popularity of direct reading methods or instruments nowadays, in contrast to older surveys where, in most cases, some modification of the Jendrassik-Grof technique wás applied $(2,3,4)$. As a direct reading method or direct spectrometric method we define a method where the spectrophotometric measurement is based on the bilirubin colour itself. The sample to be analyzed is generally diluted with a buffer. A special part of the direct reading methods is formed by the so called direct reading instruments. These instruments are designed for use with undiluted serum or plasma.

3. Sometimes a situation can occur in which more advanced medical care is reeded. This can mean that a neonate has to be transferred from one hospital to another. Ideally, this transfer means that the results of both hospital laboratories must be considered as comparable. It was interesting to know how far we were from such a situation in the Rotterdam area.

4. The application of phototherapy or exchange transfusion is at least partly based on the laboratory result of the determination of total bilirubin. Both points 3 and 4 refer to the medical side of the bilirubin determination. To a certain extent, the clinical chemist has to deal with a physician who does not demand strict precision and accuracy with respect to the determination of bilirubin in neonatal blood. That same physician, however, handles decision schemes on phototherapy and exchange transfusion $(5,6)$ and reads literature in which it is said that: ... "The indications for starting phototherapy and the length of exposure are not universally agreed ..." (7) and

... "The indications for exchange transfusion should be individualized to some extent ..." (8).

Therefore there is a need to translate those laboratory requests in to terms of accuracy and precision, as in all other aspects of clinical chemistry. 


\section{Materials and Methods}

Bilirubin

Standard bilirubin preparations in human serum, and human albumin were prepared according to the Recommandations of the well known Joint Committee (10). Bilirubin was purchased from E. Merck Co, catalogue number 24519.

\section{Albumin}

Human albumin solutions $(50 \mathrm{~g} / \mathrm{l})$ were used for the preparation of some bilirubin standard samples. The stock albumin solution (200 g/1, salt-poor) was obtained from Institut Mérieux S. A. (France).

\section{Specimens}

Sera from newborn babies (not older than 4 days) were pooled and refrigerated at $-20^{\circ} \mathrm{C}$. The serum pools were $1-4$ weeks old.

\section{Commercial bilinubin preparation}

The following commercial samples were used:

1. Versatol Pediatric (General Diagnostics), based on human serum

2. Precibil (Boehringer), based on human serum

3. Bilirubin Control (Dade), based on human albumin.

Cobalt sulphate

A Co(II)SO $\mathrm{S}_{4}$ solution (1.39 mol/1) in $0.09 \mathrm{~mol} / 1 \mathrm{H}_{2} \mathrm{SO}_{4}\left(\mathrm{H}_{2} \mathrm{SO}_{4}\right)$ was used for wavelength and absorbance check (12).

\section{Results}

During a period of five months three surveys were organized in which fifteen hospital laboratories participated. The longest distance between the organizing laboratory and a participating laboratory was $20 \mathrm{~km}$.

It was agreed, because of this small distance, that the samples should be prepared early in the morning of the "survey day", transported afterwards in well closed containers and analyzed in the afternoon of the same day in all laboratories.

The first survey took place in mid November 1978.

Because of the reasons mentioned in the Introduction, a questionnaire was enclosed. The most relevant information regarding this article is collected in table 1 .

As can be seen from table 1 the situation in the Rotterdam area is rather diverse. Part of it was known from discussion beforehand with several colleagues. Therefore it was decided to include in the first survey a bilirubin determination which was easy to perform for every participant i. e. the direct reading method of Hertz (serum dilution with borate buffer). A further advantage of this method is that it is thorougly studied (9). In' every laboratory the Hertz' method had to be checked with respect to its practical pitfalls i. e. good spectrophotometer setting and a good sample dilution.

This was done with cobalt sulphate solution (see Materials and Methods).

The first survey included five pooled baby sera, two commercial samples (human protein base) and two
Tab. 1. Information on participants. $\mathrm{n}=$ number of bilirubin determinations per month.

\begin{tabular}{|c|c|c|c|c|}
\hline $\begin{array}{l}\text { Lab. } \\
\text { No. }\end{array}$ & Method & $\begin{array}{l}\text { Photo- } \\
\text { therapy } \\
\text { Exchange } \\
\text { transfu- } \\
\text { sion }\end{array}$ & n & Calibration \\
\hline 1 & $\begin{array}{l}\text { Direct reading; } \\
\text { dilution } \\
\text { with buffer }\end{array}$ & + & 250 & $\begin{array}{l}\text { Own standard } \\
\text { (human albumin) }\end{array}$ \\
\hline 2 & $\begin{array}{l}\text { Direct rèading; } \\
\text { serum undiluted }\end{array}$ & + & 300 & $\begin{array}{l}\text { Commercial } \\
\text { standard }\end{array}$ \\
\hline 3 & $\begin{array}{l}\text { Direct reading; } \\
\text { serum undiluted }\end{array}$ & + & 50 & \\
\hline 4 & $\begin{array}{l}\text { Diazo type } \\
\text { technique }\end{array}$ & + & 200 & $\begin{array}{l}\text { Commercial } \\
\text { standard }\end{array}$ \\
\hline 5 & $\begin{array}{l}\text { Direct reading; } \\
\text { serum undiluted }\end{array}$ & + & 120 & $\begin{array}{l}\text { Commercial } \\
\text { standard }\end{array}$ \\
\hline 6 & $\begin{array}{l}\text { Direct reading; } \\
\text { serum undiluted }\end{array}$ & + & 100 & $\begin{array}{l}\text { Commercial } \\
\text { ständard }\end{array}$ \\
\hline 7 & $\begin{array}{l}\text { Direct reading; } \\
\text { dilution } \\
\text { with buffer }\end{array}$ & + & 100 & Calculated \\
\hline 8 & $\begin{array}{l}\text { Diazo type } \\
\text { technique. }\end{array}$ & + & 5 & $\begin{array}{l}\text { Commercial } \\
\text { standard }\end{array}$ \\
\hline 9 & $\begin{array}{l}\text { Direct reading; } \\
\text { serum undiluted }\end{array}$ & - & 65 & $\begin{array}{l}\text { Commercial } \\
\text { standard }\end{array}$ \\
\hline 10 & $\begin{array}{l}\text { Direct reading; } \\
\text { serum undiluted }\end{array}$ & + & 65 & $\begin{array}{l}\text { Serum sample } \\
\text { elevated bilirubin }\end{array}$ \\
\hline 11 & $\begin{array}{l}\text { Direct reading; } \\
\text { serum undiluted }\end{array}$ & + & 400 & $\begin{array}{l}\text { Commercial } \\
\text { standard }\end{array}$ \\
\hline 12 & $\begin{array}{l}\text { Direct reading; } \\
\text { serum undiluted }\end{array}$ & + & 120 & $\begin{array}{l}\text { Commercial } \\
\text { standard }\end{array}$ \\
\hline 13 & $\begin{array}{l}\text { Diazo type } \\
\text { technique }\end{array}$ & + & 50 & Calculated \\
\hline 14 & $\begin{array}{l}\text { Direct reading; } \\
\text { dilution } \\
\text { with buffer }\end{array}$ & + & 50 & $\begin{array}{l}\text { Commercial } \\
\text { standard }\end{array}$ \\
\hline 15 & $\begin{array}{l}\text { Direct reading; } \\
\text { serum undiluted }\end{array}$ & + & 65 & $\begin{array}{l}\text { Own stañdard } \\
\text { (bovine albumin) }\end{array}$ \\
\hline
\end{tabular}

bilirubin standards in human albumin. In table 2 three data sets are given: one concerning the routine method in the participating laboratories, one concerning the Hertz' techniquie and one concerning the direct reading instruments.

A number of interesting (though sometimes disappointing) remarks can be made when looking at täble 2:

1. The coefficients of variation with respect to the routine methods must be considered in our opinion as too high.

2. An important part of the large variation may be caused by the participating direct reading instruments.

3. The Hertz' technique seems to be more reliable.

Regarding this "reference method" höwever, we got the impression, based on the results of the measurements with the cobalt sulphate solution (the data are not given), that improvements could be made, even in its present application. 
Tab. 2. Results of survey 1.

\begin{tabular}{|c|c|c|c|c|c|c|}
\hline \multirow[b]{2}{*}{ Sample } & \multicolumn{2}{|c|}{$\begin{array}{l}\text { Routine method } \\
\text { of the laboratory }\end{array}$} & \multicolumn{2}{|c|}{ Hertz' technique } & \multicolumn{2}{|c|}{$\begin{array}{l}\text { Direct reading; } \\
\text { serum undiluted }\end{array}$} \\
\hline & $\begin{array}{l}\overline{\mathrm{x}} \\
(\mu \mathrm{mol} / \mathrm{l})\end{array}$ & $\begin{array}{l}\text { CV } \\
(\%)\end{array}$ & $\begin{array}{l}\bar{x} \\
(\mu \mathrm{mol} / 1)\end{array}$ & $\begin{array}{l}\text { CV } \\
(\%)\end{array}$ & $\begin{array}{l}\bar{x} \\
(\mu \mathrm{mol} / \mathrm{l})\end{array}$ & $\begin{array}{l}\mathrm{CV} \\
(\%)\end{array}$ \\
\hline $\begin{array}{l}\text { Pooled baby sera } \\
\text { Pooled baby sera } \\
\text { Pooled baby sera } \\
\text { Pooled baby sera } \\
\text { Pooled baby sera } \\
\text { Dade Bilicontrol* } \\
\text { Versatol Pediatric** } \\
\text { Own standard*** } \\
\text { Own standard*** }\end{array}$ & $\begin{array}{r}100 \\
186 \\
187 \\
183 \\
116 \\
348 \\
320 \\
98 \\
135\end{array}$ & $\begin{array}{l}15.0 \\
15.6 \\
13.4 \\
16.4 \\
13.8 \\
14.7 \\
17.2 \\
20.4 \\
11.9\end{array}$ & $\begin{array}{l}101 \\
174 \\
188 \\
174 \\
117 \\
329 \\
294 \\
108 \\
141\end{array}$ & $\begin{array}{r}4.0 \\
5.8 \\
4.8 \\
5.2 \\
5.1 \\
5.5 \\
3.7 \\
11.1 \\
12.1\end{array}$ & $\begin{array}{l}105 \\
198 \\
191 \\
195 \\
120 \\
357 \\
325 \\
105 \\
134\end{array}$ & $\begin{array}{r}10.9 \\
11.2 \\
10.4 \\
11.6 \\
11.4 \\
14.8 \\
15.3 \\
12.9 \\
8.9\end{array}$ \\
\hline
\end{tabular}

* Bilirubin in human albumin stated value $357 \mu \mathrm{mol} / 1$

** Bilirubin in human serum stated value $296 \mu \mathrm{mol} / 1$

*** Bilirubin in human albumin

Therefore we found it useful to repeat the survey with the emphasis on three points:

1. The use of the same routine methods in the same set up as in survey 1 .

2. Calculation of the results on the basis of standards in human serum (see Materials and Methods) which were prepared by the organizing laboratory and included in the sample container.

3. Improvement of the application of the Hertz' technique by each participant (wavelength check, sample dilution).

In table 3 the same data sets of survey 2, which was organized in mid December 1978, are given as in table 2.

Comparing table 2 and table 3 it is clear that we made considerable progress by using the same standards.

Therefore it seemed useful that every participant should study his results and his technique. As a consequence, a third survey had to be organized. This survey was held in April 1979.

It included a number of items:

1. A precision study between the participating laboratories with four pooled baby sera (comparable to the results mentioned in tab. 2 and tab. 3).

2. A precision study per laboratory with a standard serum sample (bilirubin content in human serum $210 \mu \mathrm{mol} / \mathrm{l})$.

3. A calibration check with three standard samples (109, 210 and $311 \mu \mathrm{mol} / 1$ in human serum)

4. A check on the influence of hemoglobin per method (hemoglobin content 0,50 and $100 \mu \mathrm{mol} / \mathrm{l}$ ).

5. A questionnaire with questions concerning the attention being paid to the surveys 1 and 2 .

Tab. 3. Results of survey 2.

\begin{tabular}{|c|c|c|c|c|c|c|}
\hline \multirow[b]{2}{*}{ Sample } & \multicolumn{2}{|c|}{$\begin{array}{l}\text { Routine method } \\
\text { of the laboratory }\end{array}$} & \multicolumn{2}{|c|}{ Hertz' technique } & \multicolumn{2}{|c|}{$\begin{array}{l}\text { Direct reading; } \\
\text { serum undiluted }\end{array}$} \\
\hline & $\stackrel{\overline{\mathbf{x}}}{(\mu \mathrm{mol} / \mathrm{l})}$ & $\begin{array}{l}\text { CV } \\
(\%)\end{array}$ & $\begin{array}{l}\overline{\mathbf{x}} \\
(\mu \mathrm{mol} / \mathrm{l})\end{array}$ & $\begin{array}{l}\text { CV } \\
(\%)\end{array}$ & $\begin{array}{l}\bar{x} \\
(\mu \mathrm{mol} / \mathrm{l})\end{array}$ & $\begin{array}{l}\text { CV } \\
(\%)\end{array}$ \\
\hline $\begin{array}{l}\text { Pooled baby sera } \\
\text { Pooled baby sera } \\
\text { Pooled baby sera } \\
\text { Dade Bilicontröl* } \\
\text { Boehringer Precibil** } \\
\text { Versatöl Pediatric*** } \\
\text { Own standard**** } \\
\text { Ọnn standard**** }\end{array}$ & $\begin{array}{l}291 \\
122 \\
242 \\
349 \\
372 \\
317 \\
291 \\
155\end{array}$ & $\begin{array}{r}5.0 \\
11.8 \\
9.6 \\
7.5 \\
5.3 \\
8.1 \\
5.5 \\
7.9\end{array}$ & $\begin{array}{l}278 \\
114 \\
226 \\
335 \\
345 \\
294 \\
318 \\
158\end{array}$ & $\begin{array}{l}4.2 \\
3.4 \\
3.7 \\
4.0 \\
3.2 \\
2.4 \\
6.3 \\
2.7\end{array}$ & $\begin{array}{l}290 \\
129 \\
251 \\
356 \\
378 \\
319 \\
291 \\
155\end{array}$ & $\begin{array}{l}4.6 \\
8.0 \\
6.9 \\
7.6 \\
4.4 \\
5.5 \\
3.7 \\
7.0\end{array}$ \\
\hline
\end{tabular}

* Bilirubin in human albumin, stated value $357 \mu \mathrm{mol} / 1$

** Bilirubin in human serum, stated value $333 \mu \mathrm{mol} / \mathrm{l}$

*** Bilirubin in human serum, stated value $296 \mu \mathrm{mol} / 1$

**** Bilirubin in humạn albumin 
Tab. 4. Results of survey 3.

\begin{tabular}{lllll}
\hline & \multicolumn{2}{l}{ Without correction } & \multicolumn{2}{l}{ With correction } \\
Sample & $\overline{\mathrm{x}}$ & $\mathrm{CV}$ & $\overline{\mathrm{x}}$ & $\mathrm{CV}$ \\
& $(\mu \mathrm{mol} / \mathrm{l})$ & $(\%)$ & $(\mu \mathrm{mol} / \mathrm{l})$ & $(\%)$ \\
\hline Pooled baby sera & 294 & 8.7 & 291 & 6.4 \\
Pooled baby sera & 268 & 8.3 & 263 & 6.2 \\
Pooled baby sera & 205 & 9.6 & 197 & 5.8 \\
Pooled baby sera & 259 & 9.5 & 255 & 7.1 \\
Standard* & 118 & 8.9 & & \\
Standard** & 313 & 5.4 & & \\
\hline
\end{tabular}

* Bilirubin standard in human serum $(109 \mu \mathrm{mol} / 1)$

** Bilirubin standard in human serum $(311 \mu \mathrm{mol} / \mathrm{l})$

In table 4 a summary is given of the precision between the laboratories without and with corrections on basis of the calibration samples.

\section{Discussion}

If we focus our attention first on the methods used in the Rotterdam area (tab. 1), then we see that, roughly speaking, three different techniques were in use at the time of the first survey:

a) direct reading methods with buffer dilution $(n=3)$

b) direct reading methods without dilution $(n=9)$

c) some modification of the Jendrassik-Grof determination $(n=3)$.

As a result of the surveys 1 and 2 some changes took place. If we take into account the changes that will take place in the near future, then nine colleagues changed their techniques and one modified his standardization procedure. This leads to the following division:

a) direct reading methods with buffer dilution $(n=9)$

b) direct reading without dilution $(n=5)$

c) the Jendrassik-Grof method $(\mathrm{n}=1)$

The second point we want to discuss regards the progress we achieved and the question of whether this progress is sufficient. As we wrote in the Introduction the physician does not ask for precision and accuracy. To our knowledge only Barnett in his article on the medical

\section{References}

1. Blijenberg, B. G. \& Leijnse, B. (1979), J. Clin. Chem. Clin. Biochem., 17, 303-308.

2. Westphal, M., Viergiver, E. \& Roth, R. (1962), Pediatrics, 29, $12-16$.

3. Schellong, G. (1963), Dtsch. Med. Wochenschr., 88, 11451152.

4. Soini, R., Dauwalder, H. \& Richterich, R. (1969), Schweiz. Med. Wochenschr., 99, 1784-1788.

5. Klaus, M. H. \& Fanaroff, A. A. (1973), Care of the highrisk neonate, p. 183, W. B. Saunders, Philadelphia.

6. Schaffer, A. J. \& Avery, M. E. (1977), Diseases of the newborn, p. 644, W. B. Saunders, Philadelphia. signifance of laboratory results mentioned a figure of 7.5 as coefficient of variation at decision levels $(340 \mu \mathrm{mol} / 1)(11)$. These data refer to full term babies embarking on exchange transfusion. What is the situation with premature infants (lower decision levels) and phototherapy (lower precision)?

We cannot give an answer to those questions. However, we considered the coefficients of variation for the routine methods (table 2) to be too high.

Table 3 shows a welcome improvement even in the Hertz' technique. The question remained as to whether this improvement would continue without guidance by the organizing laboratory. From table 4 it is clear that after a reflection period, about the same coefficients of variation were scored (column "without correction").

We still feel that more improvements can be made. If we look at the column "with correction" in table 4 and at the column "Hertz" " in table 3 then we see better coefficients of variation. Another point concerns the within-run precision and the influence of hemoglobin. Though the data are not given here it became clear from survey 3 that some collegues needed to pay more attention to the problem of imprecision and inaccuracy then they probably did. This leaves one last item, namely the direct reading instruments. An important part of the imprecision must be attributed to these instruments. This conclusion can be drawn from table 2 and 3 , as well as from the accuracy data (hemoglobin interference). The instruments used were:

a) OHC Photo Ictometer, model II and

b) the American Optical Company Bilirubinometer.

The questions that arose with these instruments are under study now and we hope to report on this study in a separate article.

\section{Acknowledgement}

We wish to thank Mrs. H. J. Brouwer for technical assistance in organizing the surveys.

Furthermore, many thanks are due to all colleagues who participated in the surveys, especially Dr. A. R. Helbing and Ir. N.C. den Boer.
7. Forfar, J. D. \& Arneil, G. C. (1978), Textbook of Paediatrics, p. 168, Churchill-Livingstone, Edinburgh, London and New York.

8. Behrman, R. E. (1977), Neonatal-perinatal Medicine, p. 410, C. V. Mosby Co, Saint Louis.

9. Hertz, H., Dybkaer, R. \& Lauritzen, M. (1974), Scand. J. Clin. Lab. Invest. 33, 215-230.

10. Recommandations on a uniform bilirubin standard (1962), Clin. Chem. 8, 405-407.

11. Barnett, R. N. (1968), Am. J. Clin. Pathol., 50, 671-676.

12. Rand, R. N. (1969), Clin. Chem., 15, 839-863.

Dr. B. G. Blijenberg

Academisch Ziekenhuis Rotterdam-Dijkzigt Department of Clinical Chemistry

Dr. Mọlewwaterplein 40

NL-3015 GD Rotterdam 